\title{
Patterns of Habitat Use by Bats Along a Riparian Corridor in Northern Utah
}

\author{
Duke S. Rogers \\ Brigham Young University - Provo \\ Mark C. Belk \\ Brigham Young University - Provo, mark_belk@byu.edu \\ Malinda W. González \\ Brigham Young University - Provo \\ Brent L. Coleman \\ Brigham Young University - Provo
}

Follow this and additional works at: https://scholarsarchive.byu.edu/facpub

Part of the Biology Commons

\section{Original Publication Citation}

Rogers, D. S., M. C. Belk, M. W. Gonzalez, and B. L. Coleman. 2006. Patterns of habitat use by bats along a riparian corridor in northern Utah. Southwestern Naturalist 51:52-58.

\section{BYU ScholarsArchive Citation}

Rogers, Duke S.; Belk, Mark C.; González, Malinda W.; and Coleman, Brent L., "Patterns of Habitat Use by Bats Along a Riparian Corridor in Northern Utah" (2006). Faculty Publications. 5456.

https://scholarsarchive.byu.edu/facpub/5456

This Peer-Reviewed Article is brought to you for free and open access by BYU ScholarsArchive. It has been accepted for inclusion in Faculty Publications by an authorized administrator of BYU ScholarsArchive. For more information, please contact ellen_amatangelo@byu.edu. 


\section{BioOne COMPLETE}

\section{PATTERNS OF HABITAT USE BY BATS ALONG A RIPARIAN CORRIDOR IN NORTHERN UTAH}

Authors: Rogers, Duke S., Belk, Mark C., González, Malinda W., and Coleman, Brent L.

Source: The Southwestern Naturalist, 51(1) : 52-58

Published By: Southwestern Association of Naturalists

URL: https://doi.org/10.1894/0038-

4909(2006)51[52:POHUBB]2.0.CO;2

BioOne Complete (complete.BioOne.org) is a full-text database of 200 subscribed and open-access titles in the biological, ecological, and environmental sciences published by nonprofit societies, associations, museums, institutions, and presses.

Your use of this PDF, the BioOne Complete website, and all posted and associated content indicates your acceptance of BioOne's Terms of Use, available at www.bioone.org/terms-of-use.

Usage of BioOne Complete content is strictly limited to personal, educational, and non - commercial use. Commercial inquiries or rights and permissions requests should be directed to the individual publisher as copyright holder.

BioOne sees sustainable scholarly publishing as an inherently collaborative enterprise connecting authors, nonprofit publishers, academic institutions, research libraries, and research funders in the common goal of maximizing access to critical research. 


\title{
PATTERNS OF HABITAT USE BY BATS ALONG A RIPARIAN CORRIDOR IN NORTHERN UTAH
}

\author{
Duke S. Rogers,* Mark C. Belk, Malinda W. González, and Brent L. Coleman \\ Department of Integrative Biology and Monte L. Bean Life Science Museum, Brigham Young University, \\ Provo, UT 84602 (DSR) \\ Department of Integrative Biology, Brigham Young University, Provo, UT 84602 (MCB, MWG, BLC) \\ *Correspondent: Duke_Rogers@byu.edu
}

\begin{abstract}
We examined patterns of habitat use within a community of bats along the Provo River in Heber Valley, Utah. The landscape was divided into 5 habitat categories: riparian forest, wetland, agricultural field, edge, and a habitat restoration site. We used Anabat II bat detectors to record the number of echolocation calls per night within each habitat type as an index of bat activity. Echolocation calls were classified into foraging guilds based on acoustic traits, and we analyzed activity by entire community and by the 4 guilds related to habitat type and environmental variables. Activity was not significantly related to moon phase, average temperature, or day of the season. Activity by the entire bat community was significantly higher in riparian forest and edge habitats compared to other habitat types. Activity of the "high" Myotis guild was significantly greater in the riparian forest, edge habitats, and in the restored habitat site. Similarly, activity by the "low" Myotis guild was significantly higher in riparian forest and edge habitats. In contrast to the Myotis guilds, activity of molossids was significantly higher in agricultural fields compared to other habitats. Activity by the "low" Eptesicus guild did not vary significantly among habitats.
\end{abstract}

RESUMEN-Examinamos los patrones de uso del hábitat en una comunidad de murciélagos a lo largo del Provo River, en el Heber Valley, Utah. El hábitat fue dividido en cinco categorías: bosque ripario, humedal, terreno cultivado, borde de hábitat, y área de restauración de hábitat. Usamos detectores de murciélagos Anabat II para registrar el número de llamadas de ecolocación por noche en cada tipo como un índice de actividad de murciélagos. Las llamadas de ecolocación fueron clasificadas en gremios de forrajeo basados en características acústicas y analizamos la actividad en toda la comunidad y en los 4 gremios relacionada con el tipo de hábitat y las variables medioambientales. La fase lunar, el promedio de la temperatura, o día de la estación no se relacionaron significativamente con la actividad. A nivel de comunidad, la actividad de los murciélagos fue significativamente mayor en el bosque ripario y en los bordes de hábitat comparada con las otras áreas de hábitat. Actividad del "alto" gremio Myotis fue significativamente más alta en el bosque ripario, en los bordes de hábitat y en el área de restauración de hábitat. Similarmente, la actividad del "bajo" gremio Myotis fue significativamente más alta en el bosque ripario y en los bordes de hábitat. En contraste con los gremios Myotis, la actividad del gremio de molósidos fue significativamente más alta en terreno cultivado comparada con otros tipos de hábitat. La actividad del "bajo" gremio Eptesicus no varió significativamente entre tipos de hábitat.

Relatively little is known regarding the degree of habitat specialization in bats, but it is assumed that the majority of insectivorous species are habitat generalists and feed opportunistically as prey is encountered (Altringham, 1996). However, some evidence suggests that some species exhibit preferences for some habitats over others. Previous studies of habitat use by feeding bats have included riparian, forest, edge, and open habitats (e.g., Fenton, 1970; Kunz, 1973; Bell, 1980; Walsh and Harris,
1996), but few studies have addressed use of multiple habitats simultaneously (Geggie and Fenton, 1985; Furlonger et al., 1987). Environmental factors that might affect habitat use by bats might include ambient temperature (Hayes, 1997; Vaughn et al., 1997), moon phase (Hayes, 1997), and time of year and time of day (Kunz, 1973; Catto et al., 1996; Patriquin and Barclay, 2003; Russo and Jones, 2003). In addition, prey availability (Fenton et al., 1977; Leonard and Fenton, 1983; Fenton, 
1990; Ekman and deJong, 1996; Vaughn et al., 1997) and vertical structure and complexity (Fenton et al., 1983; Aldridge and Rautenbach, 1987; Brigham et al., 1997) also affect feeding habitats.

The bat community in the Heber Valley of Utah consists of up to 13 species (Durrant, 1952; Harvey et al., 1999). These species exhibit variation in foraging behavior ranging from high-speed aerial hawking in open environments (e.g., Tadarida brasiliensis) to fluttering aerial insectivory (e.g., Myotis lucifugus) and surface gleaning (e.g., Myotis evotis and M. thysanodes) in more closed environments (Sherwin et al., 2000a). Typically, such foraging activities are associated with specific habitats (e.g., Fenton, 1970; Bell, 1980; Walsh and Harris, 1996). However, few studies have addressed specificity of foraging habitat use in a diverse habitat mosaic. Habitats suitable for each type of foraging behavior occur within the habitat mosaic associated with the Provo River corridor. Habitat patches are interspersed throughout the corridor, with patch sizes ranging from tens to a few hundred meters. We asked, do bats respond to specific habitat patches on this spatial scale? If bats discriminate among foraging patches at the scale at which they occur in this habitat mosaic, then we predicted variation in call numbers among habitats. If bats perceive habitat patches at a larger spatial, then we predicted no differences in call numbers among habitats.

Methods-Study Area-Our study was conducted in the historical flood plain of the Provo River in Heber Valley, Utah County, Utah $\left(40.34^{\circ} \mathrm{N}\right.$, $\left.111.26^{\circ} \mathrm{W}\right)$. Within the valley, the river runs $16.1 \mathrm{~km}$ from Jordanelle Reservoir, elevation 1,798 $\mathrm{m}$, in the north, to Deer Creek Reservoir, elevation 1,707 m, in the south. The area surveyed extended approximately $6 \mathrm{~km}$ along the river. The river was channelized during the 1940s and 1950s. Much of the historical flood plain is altered by agricultural development and urban expansion.

Five habitat types were designated along the river corridor. These were chosen based on dominant vegetation types. 1) Riparian forest has been minimally disturbed. These areas were dominated by large (approximately $10 \mathrm{~m}$ in height) trees $>40 \mathrm{y}$ of age, with a canopy mainly composed of cottonwood (Populus angustifolia), boxelder (Acer negundo), hawthorn (Crataegus), alder (Alnus incana), dogwood (Cornus florida), and willow (Salix). 2) Wetlands were natural riparian wetlands or wetlands created by the United
States Bureau of Reclamation that contained primarily cattail (Typha), hardstem bulrush (Scirpus acutus), beaked sedge (Carex utriculata), and bur-reed (Sparganium) interspersed with open water. 3) Agricultural fields were located in the historical river flood plain and consisted of crop fields or grazing lands for livestock. These areas were dominated by crop monocultures (e.g., alfalfa, corn) or pasturelands with little or no vertical structure. 4) Edgeinterface areas included the main river flow, side channels, transitional areas between forest and open land, and artificial stream banks created from large granite boulders. No understory was associated with this habitat, but the margin of trees provided moderate vertical structure. 5) One riparian habitat was restored in 1997, several years prior to this study, and was included as a specific habitat type. This area consisted of a small, newly constructed side channel of the river leading to wetlands and was included to provide information on potential bat activity in response to restoration work.

Acoustic Surveys-Acoustic surveys were used to record echolocation calls within each habitat type. Survey protocols were standardized and followed throughout the duration of the study to eliminate variability in call quality (O'Farrell, 1997). Surveys were conducted using Anabat II bat detectors (Titley Electonics, Ballina, Australia). We assumed echolocation calls to be equally detectable within all habitat types (Hayes, 2000; Sherwin et al., 2000a).

Detectors were deployed on tripods $(1.5 \mathrm{~m}$ above ground level) and connected to laptop computers or digital data recorders. The sensitivity of the detectors remained constant on all detectors throughout the study period. Detectors were set at a $45^{\circ}$ angle from vertical, with the microphone placed in a random cardinal direction. This angular position provides an optimal cone of acoustic detection. Surveys began $30 \mathrm{~min}$ after sunset and continued for 4 h. Based on previous studies, this period should detect the majority of foraging activity of bats within the community (Kunz, 1973; Thomas et al., 1987; Thomas, 1988; Hayes, 1997). Ambient temperature (in degrees C) was recorded at one-hour intervals during each survey period to evaluate the effect of this variable on bat activity in the area (Hayes, 1997).

Acoustic sample points were established wholly within described habitat types (O'Farrell and Gannon, 1999). Minimum distance between habitat edge and survey sites was $5 \mathrm{~m}$ (edge-interface areas). For the other habitat types, minimum distances were $>20 \mathrm{~m}$. Two, independent survey points were established in each habitat type (one each in the northern, upstream portion of the study area and a replicate in the southern, downstream portion of the study area), except for the single restoration site. Minimum distance between any 2 survey points was $0.6 \mathrm{~km}$, and the mean distance (range in parenthe- 
ses) between replicates was $2.6 \mathrm{~km}$ ( 1.5 to $5.3 \mathrm{~km})$. These points were identified with global positioning systems and ground verification to ensure they were consistently monitored for the duration of the study (Coleman, 2002). Surveys were conducted June through September 1999. Echolocation calls detected from free-flying bats were saved and analyzed using Anabat and Analook software (Titley Electronics, Ballina, Australia). We randomly selected up to 4 sampling sites to be monitored on any given night.

Guild Classification - Due to current debate regarding the accuracy of specific identifications, the relative role of experience, and methods of quantification of call data (Barclay, 1999; O'Farrell et al., 1999), all call sequences were categorized into acoustic guilds. Because call characteristics are correlated with flight patterns and foraging strategy (Neuweiler et al., 1984), we assumed that calls classified into these guilds were recorded from bats that behaved in a similar manner. In some instances, species could occur in more than one guild depending upon its call characteristics at the time of recording. As such, these classifications represent the "functional groups" sensu Sherwin et al. (2000a). Calls with energy $>40 \mathrm{kHz}$ were considered high frequency, while those calls with a majority of call energy $<40 \mathrm{kHz}$ were considered low frequency. Recordings were then divided based on call structure. Calls with high levels of frequency modulation were classified as Myotis type, while those with more constant frequency energy or a distinctive constant frequency phase near the terminus of the pulse energy (R. E. Sherwin, pers. comm.) were considered Eptesicus type. These criteria resulted in High Myotis, Low Myotis, High Eptesicus, and Low Eptesicus guild classifications. A fifth guild included calls with constant frequency energy $<35 \mathrm{kHz}$ and was considered Molossid type. Calls of poor quality or limited pulse energy were not classified into guild groups. Activity of bats was determined by the number of passes per hour per sample point (Crampton and Barclay, 1998).

As many as 13 species of bats occur within the study area (Durrant, 1952; Harvey et al., 1999). The species expected to comprise our functional guilds (Sherwin et al., 2000a) are as follows: High Myotis = M. lucifugus, M. californicus, and $M$ ciliolabrum; Low Myotis = M. evotis and M. thysanodes; High Eptesicus $=$ no species with these echolocation characteristics are known to occur within the study area, although Lasiurus blossevilli is known to occur elsewhere in Utah; Low Eptesicus = Lasionycteris noctivagans, E. fuscus, Lasiurus cinerus, and Corynorhinus townsendii; Molossid = Tadarida brasiliensis and Nyctinomops macrotus. Euderma maculatum and M. volans also are known from the study area; however, echolocation characteristics of these species are unclear and their guild classification, is therefore uncertain. All species within the study community produce rapid, frequency- modulated calls (feeding buzzes; Griffin et al., 1960) immediately prior to prey capture, but these were not used in guild classification.

Data Analysis-To assess whether there were differences in mean number of echolocation calls per night among habitats, we used analysis of covariance (ANCOVA, MINITAB, Minitab, Inc., State College, Pennsylvania). Habitat type was the predictor variable in the model, and average nightly temperature, moon phase, and time during the season were entered as covariates. Mean number of echolocation calls per night was not normally distributed, so call number +1 were natural $\log$ transformed for analysis. The covariate of time during the season was calculated as the number of days since the date of the first survey night. This variable was included to assess seasonal trends. Wind speed was negligible on the majority of survey nights and, thus, was not recorded. Moon phase, classified as the percent of the moon disc illuminated, was obtained from almanac records. Inasmuch as the vast majority of survey nights were either clear or partly cloudy, we considered this to be an accurate assessment of illumination. In addition to assaying whether there was variation among habitats, we tested whether there was variation in number of calls among nights. To determine if bat activity varied during sampling periods, we divided the sampling period into 4 1-h blocks within each habitat and used analysis of variance to compare number of calls among time blocks.

REsults-Acoustic surveys were conducted on 23 nights for a total of 61 4-h recordings, comprising 2,629 echolocation calls, of which 2,227 were classified into guilds (818 High $M y$ otis, 418 Low Myotis, 943 Low Eptesicus, 48 Molossid). Within each habitat type, samples were as follows: riparian forest $=10$ nights, 40 acoustic survey h; wetlands $=15$ nights, $60 \mathrm{~h}$; agriculture fields $=9$ nights, $36 \mathrm{~h}$; edge areas $=19$ nights, $76 \mathrm{~h}$; restoration site $=8$ nights, 32 h (Coleman, 2002).

The mean number of echolocation calls did not vary significantly as a function of any of the 3 covariates (Table 1 ). Activity by the entire bat community was significantly higher in the riparian forest and edge habitat relative to the other habitats (Fig. 1). Within guilds, activity of the High Myotis guild was significantly greater in the riparian forest, edge habitats, and restored habitat site. Activity of the Low Myotis guild was variable, and differed significantly among habitats. Activity was highest in riparian forest and edge habitats, intermediate in agricultural fields and the restoration site, and low- 


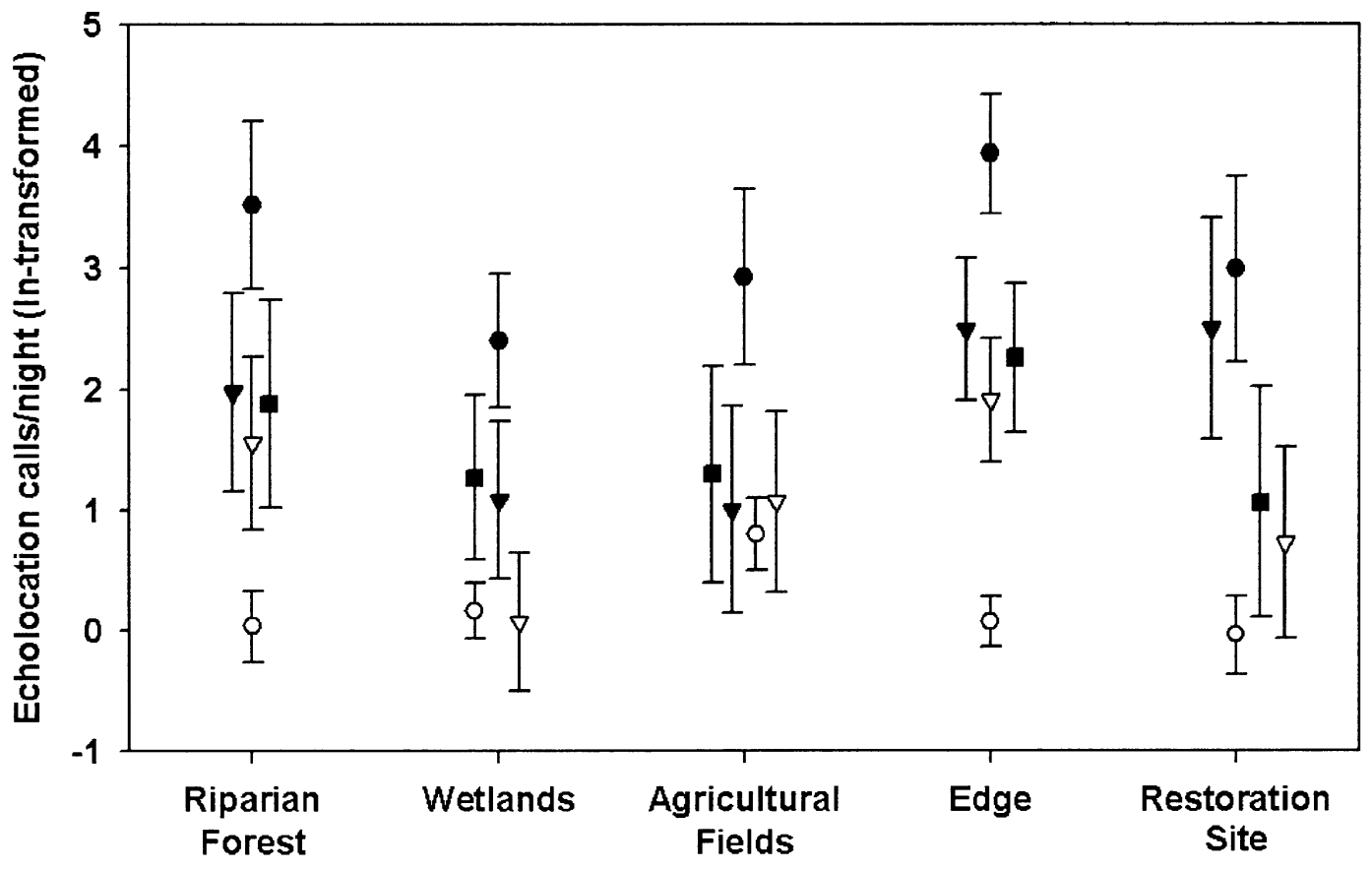

\section{Habitat type}

FIG. 1-Mean ( $\pm 2 S E$ ) number of echolocation calls per night in 5 habitat types in Utah for the entire bat community and by foraging guild. Mean number of calls is natural log transformed. Closed circle $=$ total calls; open circle $=$ Molossid guild; closed triangle $=$ High Myotis guild; open triangle $=$ Low Myotis guild; and closed square = Low Eptesicus guild. See text for descriptions of guilds.

est in wetland habitats. Activity of the Molossid guild was significantly higher in agricultural fields compared to other habitats, while activity by the Low Eptesicus guild did not vary significantly among habitats.

Discussion-In our analysis, habitat type was the most important factor influencing bat activity. Overall, bat activity was greatest along edges and in riparian forest. This pattern can be attributed primarily to habitat selection exhibited by the High and Low Myotis guilds (collectively $47 \%$ of total recorded calls), and lack of habitat selection exhibited by the Low Eptesicus guild (36\% of total recorded calls).

High and Low Myotis Guilds-Both High and Low Myotis guilds showed high activity in the riparian forest and edge habitats. This agrees with other studies examining various species of Myotis. M. lucifugus is active in a variety of clutter situations (Krusic et al., 1996; Broders et al., 2004), M. myotis adults prefer forested habitats (Audet, 1990), and M. yumanensis of all age classes predominantly forage within open, uncluttered habitats over land and low over water (Brigham et al., 1992). Myotis also exhibits higher activity in low-elevation riparian areas compared to mid-elevation or high-elevation areas (Grindal et al., 1999). Although Myotis generally seem to have preferential foraging habitats, they are not exclusive and have been observed exploiting concentrations of insects around lights in towns and rural areas (Furlonger et al., 1987).

Molossid Guild-The Molossid guild had significantly higher levels of activity in agricultural fields compared to the other habitats. Tadarida brasiliensis primarily hunts for flying insects in open areas lacking substantial obstacles and uses echolocation signals adapted to open, uncluttered spaces (Simmons et al., 1979). Wing morphology, echolocation call character- 
istics, and associated flight patterns seem to preclude this species from cluttered environments, as is the case with other large-bodied bats (Sherwin et al., 2000a; Sleep and Brigham, 2003). Although specific studies of Nyctinomops macrotus have not been done, its morphology and echolocation call characteristics are similar to T. brasiliensis, leading us to expect a similar preference for open habitats.

Low Eptesicus Guild -Within the Low Eptesicus guild, activity patterns were variable and there was no consistent habitat preferred. Both our study and others support the view that species within the Low Eptesicus guild are generalists when it comes to habitat preference for foraging. Eptesicus serotinus forages in a wide range of habitats and exploits temporary feeding habitats, such as recently mown grass (Catto et al., 1996). E. fuscus, Lasiurus cinereus, and Lasionycteris noctivagans seem unaffected by the presence of clutter in the environment (Brigham et al., 1997). Including both eastern and western subspecies, Corynorhinus townsendii also forages along the edges of streams, along canyon walls and cliff faces, over pasture and rangeland, in native oak and ironwood forests, and in sagebrush steppe and open ponderosa pine forest (Caire et al., 1984; Clark et al., 1993; Dobkin et al., 1995; Wethington et al., 1996). Such variable results are to be expected with widespread species such as C. townsendii, because any given site selected for study is certain to encompass several habitats, but cannot cover all potential habitats used by the bat. Another example of this is the observation that of several bats studied, only E. fuscus made significant use of lights in urban areas as foraging sites, while all bats (including $L$. cinereus, Lasiurus borealis, and Myotis) use lights in rural areas (Furlonger et al., 1987). Our study site did not encompass areas inhabited by humans, so this potential foraging area was excluded.

Environmental Variables-We found no significant relationship between bat activity and environmental variables (Table 1 ), but because our focus was on species groups (guilds), responses to such variables by individual species might have been masked. There is some evidence of environmental foraging activity. For example, Eptesicus capensis and Nycticeius schlieffeni altered their foraging patterns in presence of rain or bright moonlight, though the latter might have been correlated more to the pres-
TABLE 1-Results of analysis of covariance (ANCOVA) for activity by 4 guilds of bats related to habitat type and environmental variables in Utah. The model includes habitat type as the predictor variable, and mean nightly temperature, time during the survey period, and moon phase as covariates. * = significant predictors of number of echolocation calls.

\begin{tabular}{|c|c|c|c|}
\hline Variable & $d f$ & $\begin{array}{c}F- \\
\text { value }\end{array}$ & $P$ \\
\hline \multicolumn{4}{|l|}{ Total calls } \\
\hline Habitat & 4 & 4.82 & $0.0022 *$ \\
\hline Time from start of survey & 1 & 0.02 & 0.9017 \\
\hline Average nightly temperature & 1 & 0.19 & 0.6673 \\
\hline Moon & 1 & 0.88 & 0.3521 \\
\hline Error & 53 & & \\
\hline \multicolumn{4}{|l|}{ High Myotis } \\
\hline Habitat & 4 & 4.04 & $0.0062 *$ \\
\hline Time from start of survey & 1 & 0.99 & 0.3234 \\
\hline Average nightly temperature & 1 & 0.00 & 0.9832 \\
\hline Moon & 1 & 0.02 & 0.9023 \\
\hline Error & 53 & & \\
\hline \multicolumn{4}{|l|}{ Low Myotis } \\
\hline Habitat & 4 & 3.09 & $0.0233^{*}$ \\
\hline Time from start of survey & 1 & 0.38 & 0.5418 \\
\hline Average nightly temperature & 1 & 0.99 & 0.3254 \\
\hline Moon & 1 & 0.07 & 0.7982 \\
\hline Error & 53 & & \\
\hline \multicolumn{4}{|l|}{ Low Eptesicus } \\
\hline Habitat & 4 & 1.90 & 0.1238 \\
\hline Time from start of survey & 1 & 3.34 & 0.0732 \\
\hline Average nightly temperature & 1 & 0.34 & 0.5648 \\
\hline Moon & 1 & 0.53 & 0.4716 \\
\hline Error & 53 & & \\
\hline \multicolumn{4}{|l|}{ Molossid } \\
\hline Habitat & 4 & 5.08 & $0.0015^{*}$ \\
\hline Time from start of survey & 1 & 0.22 & 0.6373 \\
\hline Average nightly temperature & 1 & 0.70 & 0.4081 \\
\hline Moon & 1 & 1.55 & 0.2184 \\
\hline Error & 53 & & \\
\hline
\end{tabular}

ence of a pair of bat hawks nesting near the study site (Fenton et al., 1977). Heavy rain also inhibits foraging flights of Euderma maculatum (Leonard and Fenton, 1983). We are not suggesting that individual species do not react to environmental variation, but for the bat assemblage as a whole or as guilds, environmental variation over the range we observed had little effect on bat foraging activity.

Implication for Restoration-The Provo River 
in the Heber Valley creates a riparian corridor through a relatively dry region. Historically, the contrast between the riparian corridor and the dry surroundings, in addition to the natural variation created by the annual flood cycle of a braided river channel, resulted in a patchy environment. Such variety in habitat types probably helps support a diverse bat community by providing both roosting and foraging grounds. For example, C. townsendii is a habitat generalist with respect to foraging, but requires specific characteristics for roosting sites (Sherwin et al., 2000b). As river habitat restoration proceeds, a central goal should be to maintain and enhance this patchwork of habitat types in relatively close association.

We thank L. Woolstenhulme and 2 anonymous reviewers for comments on earlier drafts of this paper. L. Woolstenhulme also helped with data analysis. B. Gannon and R. Sherwin assisted with project design and supplied equipment. C. Corben provided technical assistance, and M. O'Farrell helped with identification of echolocation calls. We also thank R. Sherwin, T. Kallas, B. Smith, and M. Stephenson for field assistance. C. Gourly and E. Ammon provided critical logistical support. Financial support was provided by the Utah Mitigation Reclamation Conservation Commission, as well as the Zoology Department and the M. L. Bean Life Science Museum, Brigham Young University.

\section{Literature Cited}

Aldridge, H. D., And I. L. Rautenbach. 1987. Morphology, echolocation and resource partitioning in insectivorous bats. Journal of Animal Ecology 56:763-778.

AltringhaM, J. D. 1996. Bats: biology and behavior. Oxford University Press, New York.

AudeT, D. 1990. Foraging behavior and habitat use by a gleaning bat, Myotis myotis (Chiroptera: Vespertilionidae). Journal of Mammalogy 71:420427.

BARCLAY, R. M. R. 1999. Bats are not birds-a cautionary note on using echolocation calls to identify bats. A comment. Journal of Mammalogy 80: 290-296.

BeLl, G. P. 1980. Habitat use and response to patches of prey by desert insectivorous bats. Canadian Journal of Zoology 58:1876-1883.

Brigham, R. M., H. D. J. N. Aldridge, AND R. L. MACKEY. 1992. Variation in habitat use and prey selection by Yuma bats, Myotis yumanensis. Journal of Mammalogy 73:640-645.

Brigham, R. M., S. D. Grindal, M. C. Firman, AND J. L. MORISSETTE. 1997. The influence of structural clutter on activity patterns of insectivorous bats. Canadian Journal of Zoology 75:131-136.

Broders, H. G., C. S. Findlay, And L. Zheng. 2004. Effects of clutter on echolocation call structure of Myotis septentrionalis and M. lucifugus. Journal of Mammalogy 85:273-281.

Caire, W., J. F. Smith, S. McGuire, and M. A. Royce. 1984. Early foraging behavior of insectivorous bats in western Oklahoma. Journal of Mammalogy 65:319-324.

Catto, C. M. C., A. M. Hutson, P. A. Racey, and P. J. Stephenson. 1996. Foraging behaviour and habitat use of the serotine bat (Eptesicus serotinus) in southern England. Journal of Zoology 238: $623-633$.

Clark, B. S., D. M. Leslie, JR., and T. S. Carter. 1993. Foraging activity of adult female Ozark bigeared bats (Plecotus townsendii ingens) in summer. Journal of Mammalogy 74:422-427.

Coleman, B. L. 2002. Habitat utilization patterns by bats within the Provo River corridor. Unpublished M.S. thesis, Brigham Young University, Provo, Utah.

Crampton, L. H., AND R. M. R. Barclay. 1998. Selection of roosting and foraging habitat by bats in different aged aspen mixedwood stands. Conservation Biology 12:1347-1358.

Dobkin, D. S., R. G. Gettinger, and M. G. Gerdes. 1995. Springtime movements, roost use, and foraging activity of Townsend's big-eared bat (Plecotus townsendii) in central Oregon. Great Basin Naturalist 55:315-321.

DuRRANT, S. D. 1952. Mammals of Utah: taxonomy and distribution. University of Kansas Press, Lawrence.

Ekman, M., AND J. DEJong. 1996. Local patterns of distribution and resource utilization of four bat species (Myotis brandti, Eptesicus nilssoni, Plecotus auritus and Pipistrellus pipistrellus) in patchy and continuous environments. Journal of Zoology 238:571-580.

Fenton, M. B. 1970. A technique for monitoring bat activity with results obtained from different environments in southern Ontario. Canadian Journal of Zoology 48:847-851.

Fenton, M. B. 1990. The foraging behaviour and ecology of animal-eating bats. Canadian Journal of Zoology 68:411-422.

Fenton, M. B., N. G. H. Boyle, T. M. Harrison, And D. J. OxLey. 1977. Activity patterns, habitat use, and prey selection by some African insectivorous bats. Biotropica 9:73-85.

Fenton, M. B., H. G. Merriam, and G. L. Holroyd. 1983. Bats of Kootenay, Glacier, and Mount Revelstoke national parks in Canada: identification by echolocation calls, distribution, and biology. Canadian Journal of Zoology 61:2503-2508.

Furlonger, C. L., H. J. Dewar, and M. B. Fenton. 
1987. Habitat use by foraging insectivorous bats. Canadian Journal of Zoology 65:284-288.

GegGie, J. F., And M. B. Fenton. 1985. A comparison of foraging by Eptesicus fuscus (Chirpotera: Vespertilionidae) in urban and rural environments. Canadian Journal of Zoology 63:263-267.

Griffin, D. R., F. A. Webster, And C. R. Michael. 1960. The echolocation of flying insects by bats. Animal Behaviour 8:141-154.

Grindal, S. D., J. L. Morissette, And R. M. Brigham. 1999. Concentration of bat activity in riparian habitats over an elevational gradient. Canadian Journal of Zoology 77:972-977.

Harvey, M. J., J. S. Altenbach, And T. L. Best. 1999. Bats of the United States. Arkansas Game and Fish Commission, Little Rock.

Hayes, J. P. 1997. Temporal variation in activity of bats and the design of echolocation-monitoring studies. Journal of Mammalogy 78:514-524.

HAyes, J. P. 2000. Assumptions and practical considerations in the design and interpretation of echolocation-monitoring studies. Acta Chiropterologica 2:225-236.

Krusic, R. A., M. Yamasaki, C. D. Neefus, and P. J. Pekins. 1996. Bat habitat use in White Mountain National Forest. Journal of Wildlife Management 60:625-631.

KunZ, T. H. 1973. Resource utilization: temporal and spatial components of bats activity in central Iowa. Journal of Mammalogy 54:14-32.

LeONARD, M. L., AND M. B. Fenton. 1983. Habitat use by spotted bats (Euderma maculatum, Chiroptera: Vespertilionidae): roosting and foraging behaviour. Canadian Journal of Zoology 61:14871491.

Neuweiler, G., S. Singh, And K. Sripathi. 1984. Audiograms of a south Indiana bat community. Journal of Comparative Physiology 154:133-142.

O'FARRELL, M. J. 1997. Use of echolocation calls for the identification of free-flying bats. Transactions of the Western Section of the Wildlife Society 33: 1-8.

O'Farrell, M. J., B. W. Miller, and W. L. Gannon. 1999. Qualitative identification of free-flying bats using the Anabat detector. Journal of Mammalogy 80:11-23.

Patriquin, K. J., AND R. M. R. BARClay. 2003. Foraging by bats in cleared, thinned and unharvested boreal forest. Journal of Applied Ecology 40: 646-657.

Russo, D., AND G. JonEs. 2003. Use of foraging habitats by bats in a Mediterranean area determined by acoustic surveys: conservation implications. Ecography 26:197-209.

Sherwin, R. E., W. L. Gannon, and S. Haymond. $2000 a$. The efficacy of acoustic techniques to infer differential use of habitat by bats. Acta Chiropterologica 2:145-154.

Sherwin, R. E., D. Stricklan, And D. S. Rogers. $2000 \mathrm{~b}$. Roosting affinities of Townsend's bigeared bat (Corynorhinus townsendii) in northern Utah. Journal of Mammalogy 81:839-947.

Simmons, J. A., M. B. Fenton, and M. J. O'Farrell. 1979. Echolocation and pursuit of prey by bats. Science 305:16-21.

Sleep, D. J. H., AND R. M. BRigham. 2003. An experimental test of clutter tolerance in bats. Journal of Mammalogy 84:216-218.

Thomas, D. W. 1988. The distribution of bats in different ages of Douglas-fir forests. Journal of Wildlife Management 52:619-626.

Thomas, D. W., G. P. Bell, And M. B. Fenton. 1987. Variation in echolocation call frequencies recorded from North American vespertilionid bats: a cautionary note. Journal of Mammalogy 68:842847.

Vaughn, N., G. Jones, And S. Harris. 1997. Habitat use by bats (Chiroptera) assessed by means of a broad-band acoustic method. Journal of Applied Ecology 34:716-730.

WAlsh, A. L., AND S. HARRIs. 1996. Foraging habitat preferences of vespertilionid bats in Britain. Journal of Applied Ecology 33:508-518.

Wethington, T. A., D. M. Leslie, JR., M. S. Gregory, And M. K. Wethington. 1996. Pre-hibernation habitat use and foraging activity by endangered Ozark big-eared bats (Plecotus townsendii ingens). American Midland Naturalist 135:218-230.

Submitted 10 February 2004. Accepted 19 May 2005. Associate Editor was Cody W. Edwards. 